\title{
The Use of Torbangun Leaf Powder (Coleus amboinicus L) in Increasing Prolactin in Breastfeeding Wistar Rats and Body Weight of The Litters
}

\author{
Penggunaan Serbuk Daun Torbangun (Coleus Amboinicus L) dalam Meningkatkan
}

Kadar Prolaktin pada Tikus Wistar Menyusui dan Berat Badan Anak Tikus

\author{
Stella T Hasianna ${ }^{1}$, July Ivone ${ }^{2}$, Sifa D Shinta ${ }^{3}$, R Zahra Nadhira ${ }^{3}$ \\ ${ }^{1}$ Department of Physiology Faculty of Medicine Maranatha Christian University \\ ${ }^{2}$ Department of Public Health Faculty of Medicine Maranatha Christian University \\ ${ }^{3}$ Faculty of Medicine Maranatha Christian University \\ Jl. Prof. Drg. Suria Sumantri MPH No. 65 Bandung 40164 Indonesia \\ * Corresponding author \\ Email: stellatinia@gmail.com
}

Received: November 25, 2020

Accepted: February 23, 2021

\begin{abstract}
Research on local herbs that have the effect of increasing breast milk production is needed to help mothers with insufficient breastmilk. This research was conducted to determine the effect of torbangun (Coleus amboinicus L) leaf powder in increasing prolactin in breastfeeding Wistar rats and the bodyweight of the litters. Thirty breastfeeding Wistar rats were divided into 5 groups with 5 litters each. The treatments given were $108 \mathrm{mg}, 216 \mathrm{mg}$, and $432 \mathrm{mg}$ torbangun leaf powder (TLP), with domperidone as the positive control, and CMC $10 \%$ as the negative control. The treatment was given 3 times/day for 14 days. Tukey's HSD means test showed a significant difference in prolactin levels between the negative control (NC), TLP1, and $T L P 2$ groups and the TLP3 and positive control (PC) groups with all of them having $p=0.000$. There was no difference in the increase in body weight of litters between treatment groups ( $p=$ 0.866). In conclusion, torbangun leaves increase the prolactin levels in breastfeeding rats but have no difference in the increase in body weight of litters between treatment groups.
\end{abstract}

Keywords: torbangun leaves; prolactin; bodyweight; breastfeeding

\begin{abstract}
Abstrak
Penelitian mengenai herbal lokal yang memiliki efek meningkatkan produksi ASI diperlukan untuk membantu ibu yang mengalami masalah ASI kurang. Penelitian ini dilakukan untuk mengetahui pengaruh tepung daun torbangun (Coleus amboinicus $L$ ) dalam meningkatkan prolaktin pada tikus Wistar menyusui dan bobot badan anak tikus. Tiga puluh ekor tikus Wistar menyusui dibagi menjadi 5 kelompok dengan masing-masing 5 ekor anak tikus. Perlakuan yang diberikan adalah $108 \mathrm{mg}, 216 \mathrm{mg}$, dan $432 \mathrm{mg}$ serbuk daun torbangun (SDT), dengan domperidone sebagai kontrol positif, dan CMC 10\% sebagai kontrol negatif. Perlakuan diberikan 3 kali / hari selama 14 hari. Uji mean HSD Tukey menunjukkan adanya perbedaan kadar prolaktin yang bermakna antara kelompok kontrol negatif $(\mathrm{KN})$, SDT1, dan SDT2 dengan kelompok SDT3 dan kontrol positif (KP), seluruhnya memiliki $\mathrm{p}=0,000$. Tidak ada perbedaan kenaikan bobot
\end{abstract}




\section{Research Article}

badan antar kelompok perlakuan $(\mathrm{p}=0,866)$. Dapat disimpulkan bahwa daun torbangun meningkatkan kadar prolaktin pada tikus menyusui tetapi tidak ada perbedaan peningkatan bobot badan anak antar kelompok perlakuan.

Kata kunci: daun torbangun; prolaktin; berat badan; menyusu

\section{Introduction}

Breastfeeding is a natural way to provide nutrition for infants needed for their growth and development. ${ }^{1}$ The World Health Organization (WHO) recommends infants to be given exclusive breastfeeding during the first six months of life to achieve optimal growth, development, and health. ${ }^{1}$ Breastfeeding must be continued for up to two years or more. In exclusive breastfeeding, breast milk is the only source of nutrition for infants, without the addition of formula milk or other food and beverages. According to UNICEF 2018, only 41\% of infants under the age of 6 months in the world receive exclusive breastfeeding. ${ }^{2}$ In Indonesia, only $40-59 \%$ of infants under the age of 6 months get exclusive breastfeeding. The perception of insufficient breastmilk production causes a mother to use baby formula and do not breastfeed exclusively. ${ }^{3,4}$

Galactagogue is a pharmacological agent, food, or herbal supplement that is thought to help in initiating, maintaining, or increasing milk production. Worldwide, one of the reasons mothers stop breastfeeding is the perception of an inadequate supply of breastmilk..$^{5,6,7}$ The use of galactagogue is often considered for mothers whose milk production decreases and does not respond to nonpharmacological measures. ${ }^{8}$ Some plants are used in many areas to stimulate milk production in women and mammals. Galactagogue from various types of plants has been widely studied and proven to increase milk synthesis and most of these compounds are safe for humans. ${ }^{9}$

Torbangun leaves (Coleus amboinicus $L$ ) is a herb that is widely used in the community to increase milk production in nursing mothers. Several previous studies have shown that wakeup leaves contain phytochemical components of alkaloids, sterols, triterpenoids, tannins, and flavonoids which influence increase milk production, milk protein concentration, and ovulation rate, increase protein digestion and help milk production. Flavonoid compounds can also stimulate the release of prolactin (PRL) and growth hormone $(\mathrm{GH})$, upregulated expression of prolactin hormone receptor (PRLR) and growth hormone receptor (GHR) genes, and stimulate breast development. ${ }^{10-12}$ However, research on its effectiveness on increasing levels of prolactin as well as milk production and infant weight in a variety of dosage variations has not been done much so the development of research in this field is necessary. 


\section{Research Article}

The process of breastfeeding begins during pregnancy through further development in the mammary gland, in the form of an increase in the number of glands and channels of milk removal. Subsequent milk production is strongly influenced mainly by prolactin and oxytocin hormones. ${ }^{13}$ When the baby is sucking milk, there will be stimulation of the maternal breast mammary mechanism that then stimulates the hypothalamus so that the posterior pituitary gland produces oxytocin which works to stimulate the contraction of myoepithelial cells in the breast causing milk ejection. At the same time, the anterior pituitary gland also produces prolactin which acts on the alveolar epithelium encouraging milk secretion to replace milk that comes out. ${ }^{14}$ This study aims to analyze whether the administration of Torbangun leaf powder as galactagogue can increase the prolactin level of breastfeeding Wistar rats and bodyweight of the litters.

\section{Methods}

The research was conducted at the Physiology Laboratory of the Faculty of Medicine, Maranatha Christian University, and the Pharmacology Laboratory of Hasan Sadikin Hospital in Bandung. This research has received ethical approval from the Ethics Committee of the Faculty of Medicine, Maranatha Christian University Bandung No. 086 / KEP / VI / 2020.

This is a laboratory experimental study using 30 breastfeeding Wistar rats that were divided into 5 groups $(n=6)$. Each rat breastfed 5 litters in an individual cage. The rats used were healthy breastfeeding Wistar rats with first pregnancy records, descendants from genetically homogeneous (certified) rat populations, aged 8-12 weeks, and weighing 200-250 grams. The treatments given were $108 \mathrm{mg}$ (TLP1), $216 \mathrm{mg}$ (TLP2), and $432 \mathrm{mg}$ (TLP3) Torbangun leaf powder, domperidone positive control $1 \mathrm{mg}$ (PC), and negative control with CMC 10\% (NC). The dosage calculation is based on previous research regarding the dosage of torbangun leaf powder (Coleus amboinicus Lour) for breastfeeding mothers in a dose of 120gr / day and 150gr / day. ${ }^{15}$

In this study, using a dose of 150 grams of fresh torbangun leaves (Coleus amboinicus Lour) which is equivalent to 12 grams of dry powder of torbangun leaves (Coleus amboinicus Lour), converted to a dose from nursing mothers (humans) to rats. That dose is used as the middle dose, and the other two doses are half and twice of that dose. Domperidone was used as a positive control with a dose conversion from humans $(10 \mathrm{mg})$, to rats resulting in a dose of $1 \mathrm{mg}$. The treatments were given 3 times/day for 14 days, and on the 15th-day blood was taken from the rat 


\section{Research Article}

tail vein for prolactin measurement. The bodyweight of the litters was weighed $1 \mathrm{x} /$ day with digital scales using analytical scales to the nearest $0.1 \mathrm{mg}$ from birth to the 15 th day.

On the 15th day post-partum after receiving treatment for 14 days, all rats were heated by irradiating for 10 minutes and $2 \mathrm{~mL}$ of blood was taken from tail vein puncture. The blood was put into sample tube without anticoagulant, left for at least 30 minutes then centrifuged at a speed of 2500rpm for 5 minutes, after which the serum is taken and then put into an aliquot tube and sent to the laboratory for measurement of serum prolactin levels using the Cobas E 411 Analyzer with the Electrochemiluminescence Immunoassay (ECLIA) method in units of $\mathrm{ng} / \mathrm{mL}$. After the research was completely done, rats were terminated with $0.5 \mathrm{~mL}$ ketamine injection intraperitoneally, and litters were terminated by neck dislocation and buried according to the experimental animal handling procedure. ${ }^{16}$ Data were analyzed using a one-way ANOVA test, continued with Tukey's HSD multiple comparisons.

\section{Results}

After 14 days of treatment with torbangun leaves powder, an increase was obtained in the TLP1, TLP2, and TLP3 groups compared to the NC group. TLP3 dose group had the most significant effect in increasing prolactin levels compared to NC, TLP1, and TLP2. The ANOVA test results of prolactin levels between treatment groups have a p-value of 0.000 ; indicate that there is a very significant difference in serum prolactin levels between treatment groups, at least in a pair of groups. Post hoc analysis using Tukey's HSD method (Figure 1) showed the differences of prolactin level between the NC group and the TLP1 and TLP2 groups were not significant ( $\mathrm{p}=0.999$ and $\mathrm{p}=0.387$ respectively). Prolactin levels between the TLP1 and TLP2 groups differed significantly with TLP3 and PC ( $p=0,000$, respectively). 


\section{Research Article}

Figure 1 Prolactin Level among Treatment Groups after 14 days of Torbangun Leaves Powder Administration

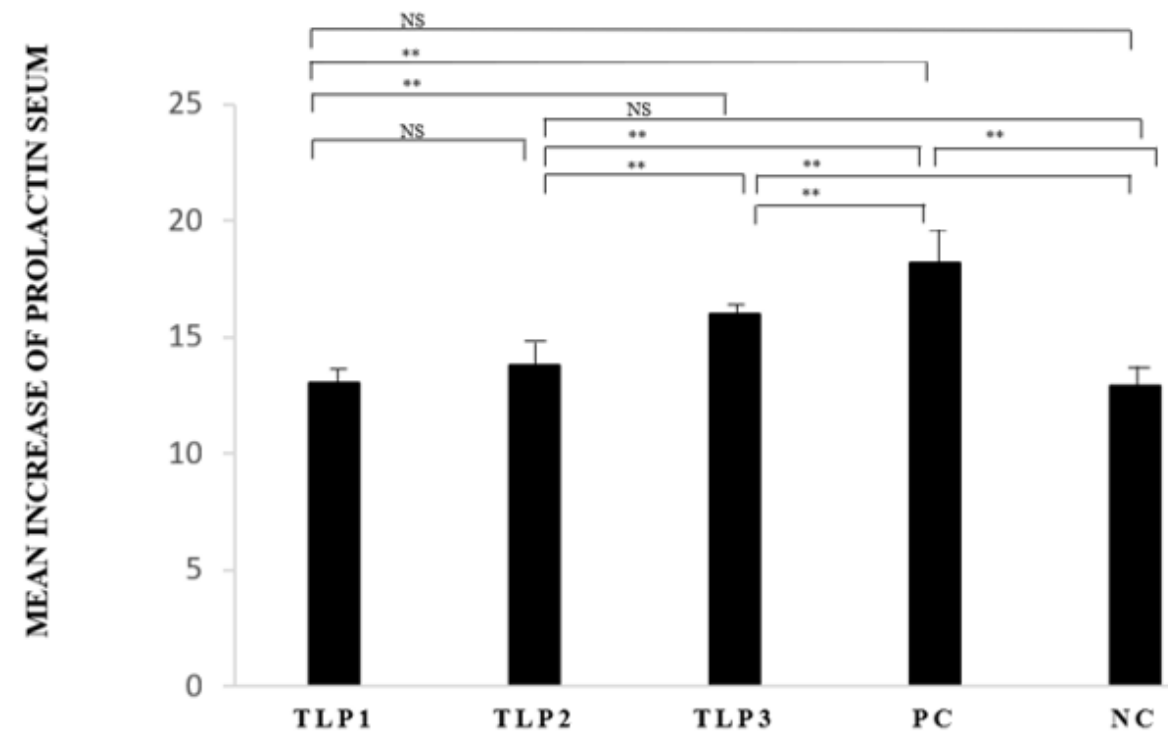

Notes:

TLP1 : Torbangun leaf powder of $108 \mathrm{mg} 3$ times/day

TLP2 : Torbangun leaf powder of $216 \mathrm{mg} 3$ times/day

TLP3 : Torbangun leaf powder of $432 \mathrm{mg} 3$ times/day

$\mathrm{PC}$ : Domperidone $1 \mathrm{mg} / \mathrm{KgBW} 3$ times/day

NC : CMC 10\% 3 times/day

ns : insignificant

: significant

*** : highyly significant

Figure 2 The Percentage Increase of the Litters' Body Weight

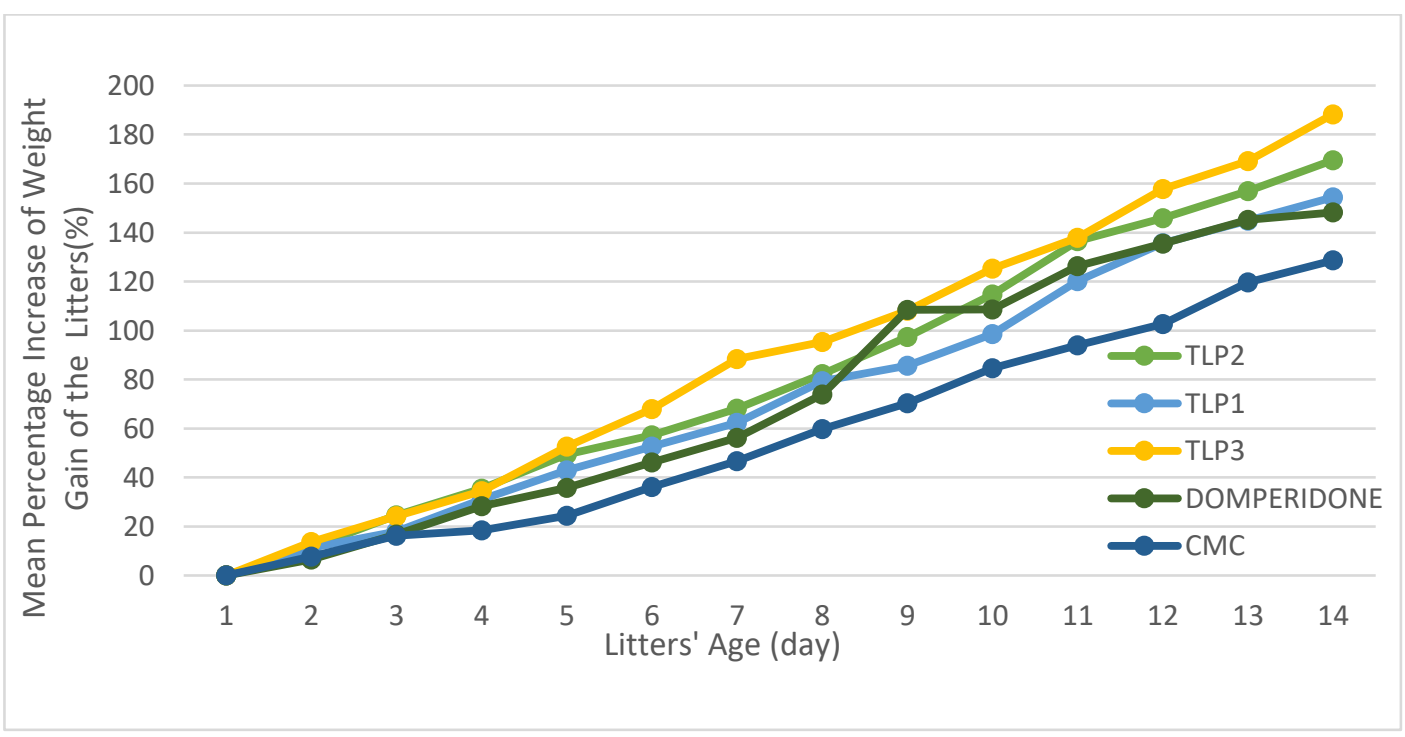




\section{Research Article}

Figure 2 shows the mean percentage increase in body weight of litters who were breastfed when given the treatment for 14 days compared to the litter's weight at birth. The mean percentage increase in litter bodyweight from the highest to the lowest was in the TLP 3, TLP 2, TLP 1, PC, and NC groups. ANOVA test results obtained $\mathrm{p}=0.866$, which means there was no difference in the increase in body weight of litters between treatment groups.

\section{Discussion}

According to Iwansyah et al.'s research on Torbangun leaves, there are several phytochemical components in torbangun such as sterols, oliphenols, triterpenoids, tannins, flavonoids, active components p-coumaric acid, rosmarinic acid, chysoeriol, eriodictyol, luteolin, quercetin, routine, 5,4'-dihydroxy-6,7-dimethoxy flavones, 5,4'-dihydroxy-3,7-dimethoxy flavones, 5-o -methyl-luteolin, and apigenin which can increase the production of prolactin hormone (PRL) and growth hormone (GH), upregulate prolactin hormone receptor (PRLR) and GHR gene expression and stimulate breast development in vasectomy rats. ${ }^{12}$

This study found that torbangun leaves effectively increase prolactin levels in TLP3 compared to TLP1 and TLP2, but this increase is not as effective as in PC. PC group treated with domperidone showed an increase in prolactin level with very significant difference compared to the treatment groups (TLP1, TLP2, TLP3) and NC. Domperidone has an antidopaminergic effect and can direct adenohypophysis stimulation to suppress hypothalamic secretion from PRL inhibitors (PIF) and stimulation of the hypothalamus to release PRL-releasing hormone so that it increases serum prolactin in breastfeeding and non-breastfeeding women. ${ }^{17,18}$ In a previous study, breastfeeding rats treated with the ethyl acetate fraction of Torbangun leaves every two days starting from day 2 after giving birth until day 14 showed an increase of milk production by $17 \% .^{12}$

3-ethyl-3-hydroxy-5-alpha andostran-17-one, 3,4-dimethyl-2- oxocyclopent-3enylaceticacid, monomethyl succinate, and methylopyroglutamate in 10-15 in torbangun leaves stimulate the release of the hormones estrogen and progesterone more than usual from the ovaries, thereby increasing the proliferation of the alveolar epithelium of the mammary gland which refers to increased milk production. ${ }^{11}$ Adequate breastmilk production can meet the needs of feeding rats, especially in early life. Research by Iwansyah, et al, and research by Hutajulu, et al, supports the increase in body weight of breastfeeding rats when the mother is given torbangun leaf supplementation as a stimulant for breast milk production. ${ }^{12,19}$ 


\section{Research Article}

The bodyweight of breastfeeding rats increased according to the dose given. The negative control group (NC) had the lowest mean percentage increase in body weight of breastfeeding litters $(128.62 \%)$. However, the ANOVA test showed that there is no significant differences among treatment groups. The litters' stomach capacity is more or less the same so that the amount of breast milk that can be consumed is more or less equal. ${ }^{19}$ This research did not directly measure the amount of breastmilk produced hence there might be differences between the amount of breastmilk produced and the amount of breastmilk that is ingested by the litters. Another reason for the insignificant differences between groups might be because all the rats used in this research were healthy rats without certain conditions. In medical conditions with impaired breastmilk production such as diabetes mellitus, thyroid dysfunction, polycystic ovarian syndrome, or obesity, the effect of galactagogue might be enhanced. ${ }^{20,21}$

The saponin content, which is one of the active substances from torbangun leaves, affects absorption in the rat intestine by inhibiting nutrient transport, active substances and facilitating the uptake of substances that should not be absorbed. This causes an increase in permeability of the small intestine mucosa. ${ }^{21}$ The absence of an increase in the mean percentage of body weight of breastfeeding rats is also thought to occur because the stomach capacity of the litters is relatively smaller than adult rats so it is suspected that not all breast milk products can be ingested by litters, although there is an increase Breast milk production as in a study by Mangkuji B, et al, which examined the provision of steeping torbangun leaf tea can increase milk production but does not guarantee that all breast milk is ingested. ${ }^{22}$ Further research on the effect of torbangun leaves on the weight gain of breastfeeding rats is still needed considering there are still many limitations in this study.

\section{Conclusion}

Torbangun leaves increase the prolactin levels in breastfeeding rats but have no difference in the increase in body weight of litters between treatment groups.

\section{References}

1. WHO. WHO | Breastfeeding. World Health Organisation. 2013.

2. UNICEF. Infant And Young Child Feeding - UNICEF Data. UNICEF. 2018.

3. UNICEF. Ringkasan Kajian Kesehatan Ibu \& Anak. UNICEF Indonesia. 2012.

4. Balitbangkes Kemenkes. Hasil Utama Riset Kesehatan Dasar (Riskesdas). 2018.

5. Brown Cr, Dodds L, Legge A, Bryanton J, Semenic S. Factors Influencing The Reasons Why Mothers Stop Breastfeeding. Can J Public Health. 2014 May 9;105(3):E179-85.

6. Gbadamosi I, Okolosi O. Botanical Galactogogues: Nutritional Values And Therapeutic Potentials. J Appl Biosci. 


\section{Research Article}

2013; 61: 4460-9.

7. Steyn N, Zunza M, Decloedt EH. A Cross-Sectional Descriptive Study of Breastfeeding Behaviour And Galactogogue Use Among Private-Sector Patients In Cape Town, South Africa. S Afr J Obstet Gynaecol. 2017; 23(1):20-3.

8. Mortel M, Mehta SD. Systematic review of the efficacy of herbal galactogogues. J Hum Lact. 2013;29(2):154-62.

9. Tabares FP, Jaramillo Jvb, Ruiz-Cortés Zt. Pharmacological Overview Of Galactogogues. Vet Med Int. 2014; 2014:1-20.

10. Damanik RM, Kustiyah L, Hanafi M, Iwansyah Ac. Evaluation Lactogenic Activity Of Ethyl Acetate Fraction Of Torbangun (Coleus Amboinicus L.) Leaves. IOP Conf.Ser.:Earth Environ. Sci. 2017;101:1-10.

11. Suryowati T, Damanik R, Bintang M, Handharyani E. Identifikasi Komponen Kimia dan Aktivitas Antioksidan dalam Tanaman Torbangun (Coleus Amboinicus Lour). J Gizi dan Pangan. 2015;10(3):217-24.

12. Iwansyah Ac, Damanik Mrm, Kustiyah L, Hanafi M. Potensi Fraksi Etil Asetat Daun Torbangun (Coleus Amboinicus L.) Dalam Meningkatkan Produksi Susu, Bobot Badan Tikus, dan Anak Tikus. J Gizi dan Pangan. 2017 Mar;12(1):61-8.

13. Lawrence R, Lawrence RM. Breastfeeding. A Guide for the Medical Profession. 5th ed. St. Louis, MO: MosbyYear Book, Inc; 2005.

14. Sherwood L. Introduction To Human Physiology. 8th Ed. United States: Brooks/Cole Cengage Learning; 2013. p.692-830.

15. Syarief H, Damanik RM, Sinaga T, Doloksaribu TH. Pemanfaatan Daun Bangun-Bangun Dalam Pengembangan Produk Makanan Tambahan Fungsional Untuk Ibu Menyusui. J Ilmu Pertan Indones. 2014;19(1):38-42.

16. Leary S, Underwood W, Anthony R, Cartner S. Avma Guidelines For The Euthanasia Of Animals: 2013 Edition. American Veterinary Medical Association. 2013. 48-51 P.

17. Gabay Mp. Galactogogues: Medications That Induce Lactation. J Hum Lact. 2002;18(3):274-9.

18. Haase B, Taylor Sn, Mauldin J, Johnson Ts, Wagner Cl. Domperidone For Treatment of Low Milk Supply In Breast Pump-Dependent Mothers Of Hospitalized Premature Infants: A Clinical Protocol. J Hum Lact. 2016;32(2):37381.

19. Hutajulu T, Junaidi L. Manfaat Ekstrak Daun Bangun-Bangun (Coleus Emboinicus L.) untuk Meningkatkan Produksi Air Susu Induk Tikus. J Ind Res. 2013;7(1):15-24.

20. Lou Z, Zeng G, Huang L, Wang Y, Zhou L, Kavanagh Kf. Maternal Reported Indicators and Causes of Insufficient Milk Supply. J Hum Lact. 2014;30(4):466-73. 21.

21. Johnson IT, Gee JM, Price K, Curl C, Fenwick GR. Influence of saponins on gut permeability and active nutrient transport in vitro. J Nutr. 1986;116(11):2270-7.

22. Mangkuji B, Siregar Y, Lovita B. Pengaruh Seduhan Teh Daun Bangun-Bangun terhadap Produksi ASI di Desa Selayang Wilayah Kerja Puskesmas Selesai Kecamatan Selesai Kabupaten Langkat Tahun 2018. J Ilm PANNMED. 2018;13(1):7-9. 